\title{
Pyopneumopericardium and empyema thoracis from perforated oesophageal cancer
}

\author{
Nitinan Chimparlee, ${ }^{1}$ Monravee Tumkosit, ${ }^{2}$ Kittichai Luengtaviboon, ${ }^{3}$ \\ Pairoj Chattranukulchai ${ }^{4}$
}

'Department of Biochemistry, Faculty of Medicine, Chulalongkorn University, Bangkok, Thailand 2Department of Radiology, Faculty of Medicine, Chulalongkorn University, Bangkok, Thailand ${ }^{3}$ Division of Cardiothoracic Surgery, Department of Surgery, Faculty of Medicine, Chulalongkorn University, Bangkok, Thailand ${ }^{4}$ Division of Cardiology, Department of Medicine, Faculty of Medicine, Chulalongkorn University, Cardiac Center, King Chulalongkorn Memorial Hospital, Bangkok, Thailand

Correspondence to Dr Pairoj Chattranukulchai, pairoj.md@gmail.com

\begin{tabular}{|l|}
\hline To cite: Chimparlee N, \\
Tumkosit M, \\
Luengtaviboon K, et al. BMJ \\
Case Rep Published online: \\
[please include Day Month \\
Year] doi:10.1136/bcr-2013- \\
010053 \\
\hline
\end{tabular}

\section{DESCRIPTION}

A 79-year-old Thai man with a history of untreated mid-oesophageal cancer presented with progressive dyspnoea and productive cough for 3 weeks. On examination, he had low-grade fever, tachyponea, regular pulse rate at $110 / \mathrm{min}$, blood pressure 120 / $78 \mathrm{~mm} \mathrm{Hg}$ without definite pulsus paradoxus. Pulmonary examination showed mild deviation of trachea to the right, dullness on percussion and decreased breath sound at the left lung. He also had mildly distended neck veins, decreased cardiac sound and decreased apical impulse. ECG revealed sinus tachycardia with low QRS voltage without significant ST-T change. A large amount of generalised high-echoic pericardial fluid and evidences of early cardiac temponade were demonstrated by transthoracic echocardiography.

Contrast-enhanced CT of the chest showed known circumferential oesophageal mass at the middle one-third of the oesophagus (black asterisk, figure 1A). A large amount of circumferential pericardial fluid (white asterisks, figure $1 \mathrm{~A}-\mathrm{C}$ ) with small air bubbles (bold arrows, figure 1A-C) were detected. In addition, large loculated fluid collections in left hemithorax with air-fluid level and pleural enhancement (open arrows, figure 1A,C) were observed. Subsequent pericardiocentesis along with left intercostal drainage were performed, which revealed similar findings of large volume of frank, yellowish, foul-smelling pus (figure 2), consistent with pyopneumopericardium and empyema thoracis. On the basis of these findings, the patient underwent surgery with the presumptive diagnosis of the perforation of necrotic oesophagus leading to direct spread of infection to adjacent organs. Intraoperative finding confirmed the ruptured oesophagus at mid-thoracic level as a consequence

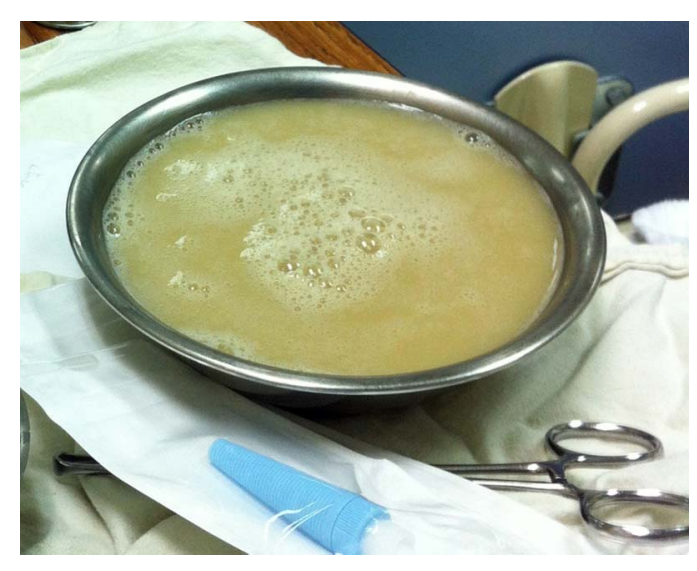

Figure 2 Frank, yellowish, foul-smelling pus from pericardiocentesis which appeared similar to empyema thoracis from intercostal drainage. Microbiological culture was positive for mixed organisms including Pseudomonas aueruginosa, Streptococcus group D and Streptococcus group $G$.

of local tumour invasion. He successfully underwent combined drainage of pus in pericardial space with pericardiectomy, decortication of left lung and resection of the thoracic oesophagus from just below aortic arch to oesophagogastric junction. Microbiological cultures of pus were positive for mixed organisms including Pseudomonas aueruginosa, Streptococcus group D and Streptococcus group G. Postoperative period was uneventful and he is currently in the restoration process of enteral alimentation before being discharged.

Perforation of oesophageal cancer is a serious circumstance that most often results from either diagnostic or therapeutic instrumentation, that is, stent placement. ${ }^{1}$ Locally advanced cancer may lead to 
spontaneous perforation of oesophagus which has high mortality rate. ${ }^{2}$ This allows progressive migration of the normal bacterial flora from the oesophagus to adjacent mediastinal organs include of the pericardial sac and pleural cavity leading to uncontrolled infection. ${ }^{4}$ Pyopneumopericardium and empyema thoracis are very rare, but recognised, complications which dictate prompt surgical therapy.

\section{Learning points}

- Perforation of oesophageal cancer is a serious circumstance that most often results from either diagnostic or therapeutic instrumentation.

- Advanced oesophageal cancer may lead to spontaneous perforation from local tumour invasion.

- Pyopneumopericardium and empyema thoracis are very rare complications as a result of progressive migration of the normal bacterial flora from the oesophagus to adjacent mediastinal organs.
Contributors NCand PC wrote the manuscript. MT, KL reviewed and revised the manuscript.

Competing interests None.

Patient consent Obtained.

Provenance and peer review Not commissioned; externally peer reviewed.

\section{REFERENCES}

1 Huber-Lang M, Henne-Bruns D, Schmitz B. Esophageal perforation: principles of diagnosis and surgical management. Surg Today 2006;36:332-40.

2 Reeder LB, DeFilippi VJ, Ferguson MK. Current results of therapy for oesophageal perforation. Am J Surg 1995;169:615-17.

3 Bhatia P, Fortin D, Inculet Rl, et al. Current concepts in the management of esophageal perforations: a twenty-seven year Canadian experience. Ann Thorac Surg 2011;92:209-15.

4 Piatkowski R, Kochanowski J, Karpiński G, et al. Purulent pericarditis in patient with esophageal cancer presenting with cardiac tamponade. J Emerg Med 2011;40:671-3.

Copyright 2013 BMJ Publishing Group. All rights reserved. For permission to reuse any of this content visit http://group.bmj.com/group/rights-licensing/permissions.

BMJ Case Report Fellows may re-use this article for personal use and teaching without any further permission.

Become a Fellow of BMJ Case Reports today and you can:

- Submit as many cases as you like

- Enjoy fast sympathetic peer review and rapid publication of accepted articles

- Access all the published articles

- Re-use any of the published material for personal use and teaching without further permission

For information on Institutional Fellowships contact consortiasales@bmjgroup.com

Visit casereports.bmj.com for more articles like this and to become a Fellow 